\title{
What options are available to Scotland to remain within the EU given the 'Brexit' referendum result?
}

\section{Maria Fletcher (University of Glasgow) and Rebecca Zahn (University of Strathclyde)}

The 23 June 2016 referendum result has the potential to impact hugely on Scotland's relationship with the European Union and indeed with the rest of the UK. Within the framework of the current devolved settlement in the UK, withdrawal from the EU by the UK following activation of the EU's 'exit clause', will mean that Scotland also leaves the UK, despite a significant majority of the Scottish electorate voting to 'remain'. In legal terms, the United Kingdom as a state recognised under international law, is the signatory to the European Treaties. Withdrawal of that state, includes its constituent parts.

\section{Independence}

The referendum result which saw an overall UK vote to Leave the European Union but a 62/38\% vote in favour of Remain in Scotland, has prompted calls from the First Minister of Scotland to 'take all possible steps and explore all options to give effect to how people in Scotland voted.' ${ }^{1}$ One of these options is a second independence referendum in Scotland, which the First Minister, described in the immediate aftermath of the 23 June vote, as 'highly likely' in the next two-and-a-half years following the UK's vote to leave the EU. Should Scotland democratically secede from the UK it would then be in a position to be a member of the EU in its own right. An independent Scotland would be the clearest legal route to membership of the EU should the UK leave. The clearest, but by no means guaranteed, let alone quick and easy. As with the first independence referendum, an agreement would need to be reached between Holyrood and Westminster to provide the necessary legislative competence for this to take place, and negotiations required with the EU in order to reorder Scotland's relationship therewith. Assuming this could achieved, the particular EU legal route (Article 48 or $49 \mathrm{TEU}$ ) to such membership for Scotland is also contested]. the traditional accession route for any non-EU State (Article 49 TEU) would place Scotland alongside a number of other States in that particular queue and down a route of full EUacquis adoption, thus relinquishing the current UK-negotiated scenario of opt-outs from the euro and Schengen for instance. Alternatively Article 48 TEU provides for the Treaties to be amended by unanimous consent of the Member States and is sometimes referred to as a basis for allowing 'internal enlargement.' Assuming there is the political will to use Article 48 TEU and assuming matters of timing permit, there could be a seemless transition from Scotland's membership of the EU as part of the UK and its membership of the EU as an independent State on Brexit day. ${ }^{2}$

\section{Could Scotland remain in the EU without seeking independence?}

A second and parallel on-going discussion to the Scottish independence route to EU membership is whether Scotland could remain in the EU without seeking independence.

\footnotetext{
${ }^{1} \mathrm{http}: / /$ stv.tv/news/politics/1358534-nicola-sturgeon-speech-in-full-after-eu-referendum-result/

${ }^{2}$ For a helpful summary of the Article 48 and 49 TEU issue in relation to Scotland see http://verfassungsblog.de/a-european-future-for-scotland/
} 
Could England and Wales effectively withdraw their membership of the EU and the UK's membership somehow be retained through a relationship with Scotland (and Northern Ireland)? Certainly, this would require a high level of political will and legal creativity at both the UK and the EU level. It is instructive to study and learn from existing examples of the EU's considerable flexibility - where it has accommodated differential territorial application of EU law within a Member State ${ }^{3}$ - but there is no 'off the peg' arrangement which would allow Scotland to both remain in the EU while also remaining part of the UK. A number of precedents have been cited where different parts of a Member State have different relationships with the EU. Examples include Greenland, the Channel Islands and the Isle of Man, and Cyprus. Indeed, territorial differentiation - where different parts of EU law apply to different parts of a Member State - is not uncommon. ${ }^{4}$ However, they differ from the Scottish example in that in all of these cases the metropolitan State participates fully in the EU. In addition, the only historical example where part of a territory of a Member State has left the EU while the rest of a Member State has remained an EU member can be found in Denmark/Greenland. In 1985 Greenland, constitutionally a part of Denmark, chose to leave the EU and became the only country ever to do so. So in essence, part of Denmark is outside the EU and part of it remains in the EU. ${ }^{5}$ This has led some commentators to consider whether a 'Reverse Greenland' model could be used to allow Scotland (and Northern Ireland) to remain within the EU without seceding from the UK. ${ }^{6}$ In theory, this may be legally possible with the requisite consent of the UK and EU parties ${ }^{7}$, but the UK situation is materially different from the Danish situation and the legal and political obstacles to such a solution are considerable.

Greenland represents $1 \%$ of the overall population of Denmark and is geographically isolated from it and Europe. Greenland is for almost all internal affairs a self-governing country, with Danish responsibility limited essentially to foreign affairs, monetary policy, citizenship and defence. A tiny, distant and highly autonomous part of Denmark therefore sought to leave the EU. In the case of Scotland a small (8\%), geographically attached and (relatively) less autonomous part of the UK would seek to remain in the EU while the bulk of the UK would

\footnotetext{
${ }^{3}$ We need not look any further than our shores to know that different state configurations are possible and that the EU does and can accommodate differential participation (eg. Gibraltar). In fact the UK is one of six Member States with territories holding certain special statuses in EU law. Overseas countries and territories (OCTs) are a distinct grouping in the EU and have their own agreements (for which provision is made in Articles 198-204 of the Treaty on the Functioning of the European Union (TFEU)) which regulate their relationships with the EU.

${ }^{4}$ See more broadly D Kochenov (ed), On Bits of Europe Everywhere. Overseas Possessions of the EU Member States in the Legal-Political Context of European Law (The Hague, Kluwer Law International, 2011). For an overview of the usefulness of this concept in the Scottish case see N. Skoutaris, From Britain and Ireland to Cyprus: Accommodating 'Divided Islands' in the EU Political and Legal Order, EUI Working Paper AEL 2016/02

${ }^{5}$ The Greenland Treaty introduced a clause into the EEC and Euratom Treaties stating that 'this Treaty shall not apply to Greenland' and added Greenland as one of the overseas territories of the Member States, in what is now Annex II to the Treaties.

${ }^{6}$ See for instance http://blogs.lse.ac.uk/europpblog/2016/07/07/reverse-greenland-arrangement/ and T Lock, 'A European Future for Scotland?', available at verfassungsblog.de/a-european-future-for-scotland/; https://www.opendemocracy.net/uk/adam-ramsay/reverse-greenland-letting-scotland-stay ${ }^{7}$ For the argument that the 'withdrawal' of (for instance) England and Wales from the EU might be legally attainable by changing the provision on the territorial application of the EU Treaties rather than activating Article 50 TEU see https://ukconstitutionallaw.org/2016/06/30/leonard-besselink-beyond-notification-how-toleave-the-european-union-without-using-article-50-teu/
} 
be outside of it. Moreover, some of the many practical problems created by such a scenario include the required adjustment to the current division of competences between Holyrood and Westminster (at least) to enable Scotland to engage in external relations and those associated with the creation of an internal border within the UK for goods and persons. ${ }^{8}$

The example of Cyprus's relationship with the EU may be instructive in this regard. As Skoutaris points out, 'Cyprus is the only Member State where the acquis does not apply to a significant part of its territory and there is a territorial border between the part where it applies and where it does not." 9 The application of the EU's acquis is suspended in the northern part of Cyprus, which is effectively controlled by Turkey (Protocol No 10 of the Treaty of Accession 2003). As long as that suspension is not withdrawn Article 2 of the Protocol allows the Council to define the terms under which the provisions of EU law apply to the 'Green Line' i.e. the de facto 'territorial border'. The so called Green Line Regulation ${ }^{10}$ regulates the free crossing of people and goods between an area of a Member State where the free movement acquis applies and is within the customs union and one where the free movement acquis does not apply and is outside the customs union. ${ }^{11}$ Should a similar approach be adopted in the UK context - to enable the application of EU law to be suspended in England and Wales and only continue to apply to Scotland and Northern Ireland, similar difficult practical issues relating to the creation of an internal border for goods and persons would need to be face and resolved. hard customs border and border checks within the territory of the UK. Beyond this, significant constitutional amendment to the devolution arrangement would have to take place in order for both regions to take part effectively in the political and constitutional life of the EU. And last, but by no means least, the UK Government would need to consent to not formally withdrawing from the EU - and that particular ship appears to have sailed. ${ }^{12}$

A final option may be to consider to what extent Scotland could continue to benefit from EU laws in the event of the UK's (and therefore Scotland's) withdrawal from the EU.

How could Scotland continue to benefit from EU laws in the event of the UK's withdrawal from the EU?

The extent to which Scotland could continue to benefit from EU laws in the event of the UK's withdrawal from the EU depends on the future relationship between the EU and the UK. Potential options include (continued) membership of the European Economic Area (EEA) and/or the European Free Trade Association (EFTA); a series of bilateral deals with

\footnotetext{
${ }^{8}$ cite Aileen McHarg's list of queries (in earlier Ed Law Review piece)

${ }^{9}$ N. Skoutaris, From Britain and Ireland to Cyprus: Accommodating 'Divided Islands' in the EU Political and Legal Order, EUI Working Paper AEL 2016/02, p. 9.

${ }^{10}$ Council Regulation (EC) No 866/2004 of 29 April 2004. N Skoutaris, 'The application of the acquis communautaire in the areas not under the effective control of the Republic of Cyprus: The Green Line Regulation', 45 Common Market Law Review (2008) 727.

${ }^{11}$ N.Skoutaris, ibid. n. 8

12 'Brexit: Article 50 will be triggered by end of March 2017, Theresa May' see http://www.independent.co.uk/news/uk/politics/article-50-theresa-may-march-2017-brexit-a7341236.html
} 
the EU; or a 'hard' Brexit whereby the UK's relationship with the EU is governed by the World Trade Organisation's rules. ${ }^{13}$

In any case, a transition period after the UK exits the EU is likely during which the UK's rights and obligations as an EU Member State are phased out. ${ }^{14}$ EU law may therefore continue to apply to pending disputes which began before UK withdrawal from the EU. In addition, UK common law may, in some areas such as employment law, lead to the continuing application of some standards of EU law. In the area of employment law, judges have shown themselves as remarkably adept at recognising not only economic and social conditions but also legal constructs which are prejudicial to workers, and have expanded the common law when necessary. Judges may well therefore find ways to uphold those rights derived from EU law which have become part of UK law following Brexit. ${ }^{15}$

The outcome of the negotiations over Brexit is, for obvious reasons, difficult to predict. Should the UK negotiate (continued) membership of the EEA then access to the single market is secured and most current and future EU laws on free movement of goods, services, people and capital would continue to apply to the UK and, therefore by extension, to Scotland. Certain safeguard clauses in the EEA agreement might be sufficient to satisfy a desire for control over immigration ${ }^{16}$ and significant policy matters such as agriculture, fisheries, tax and non-EU trade are not within the scope of the EEA, possibly making it a more attractive option (even if on an interim basis) for the UK and Scotland. Finally, the case law of the EFTA Court and relevant case law of the Court of Justice of the European Union would apply.

The UK could also negotiate a series of bilateral agreements governing its future relations with the EU, akin to the EU-Switzerland relationship. Switzerland has signed over one hundred bilateral treaties with the EU enabling it to participate in different EU policies or programmes. ${ }^{17}$ In addition, Switzerland is a member of EFTA which provides for free trade with the EU in all non-agricultural goods. In those areas covered by bilateral treaties, Switzerland has committed to observing significant amounts of EU law. ${ }^{18}$ As a result, the EU

\footnotetext{
${ }^{13}$ For a more detailed overview see Chalmers, Davies and Monti 'The Authority of EU Law beyond the Union'.

${ }^{14}$ Chalmers and Menon advocate for a speedy exit followed by a lengthy transition phase during which the terms of the future relationship are negotiated. They anticipate a closer relationship for Scotland (and possibly Northern Ireland) with the EU than other parts of the UK, which might involve Scotland keeping EU law in place in return for informal participation in the Committee of Permanent Representatives (COREPER), the body of civil servants which prepare Council of Ministers meeting. See http://openeurope.org.uk/intelligence/britainand-the-eu/3-step-brexit-solution/

${ }^{15} \mathrm{http}$ ://blog.oup.com/2016/06/filling-void-brexit-employment-law/

16 See for a comprehensive and positive account of the EEA option - http://www.adamsmith.org/evolution-notrevolution. However, the safeguard clause can only be invoked according to strict criteria (If serious economic, societal or environmental difficulties of a sectorial or regional nature liable to persist are arising) and EU States could retaliate by imposing limits on the free movement of goods or services. For more information see: http://eulawanalysis.blogspot.co.uk/2016/06/what-next-after-uk-vote-to-leave-eu.html.

${ }^{17}$ See further S. Lavenex, 'Switzerland's Flexible Integration in the EU: A Conceptual Framework' (2009) 15 Swiss Political Science Review 547.

${ }^{18}$ See further R. Schwok, 'Switzerland's Approximation of its Legislation to the EU Acquis: Specificities, Lessons and Paradoxes' (2007) 9 European Journal of Law Reform 447. Swiss authorities have also adopted the policy of autonomous adoption ('autonomer Nachvollzug') of EU laws which means that EU laws have a
} 
has closer ties with Switzerland than with any other non-EEA country. However, this relationship is not unproblematic ${ }^{19}$, particularly in the wake of a Swiss referendum in February 2014 which voted, in breach of Swiss obligations on Schengen, to impose quotas on the number of EU citizens who could reside in Switzerland. ${ }^{20}$ The EU has responded by stating its intention to withdraw from any negotiations on the internal market if the principles of non-discrimination, freedom of establishment and right to reside are not respected.

At the time of writing, it is unclear what is the desired future relationship between the UK and the EU. The British Prime Minister has however announced that the Government plans to trigger the Article 50 withdrawal process by the end of March 2017 and that the next Queen's Speech will include a "Great Repeal Bill" whose primary objective will be to repeal the European Communities Act 1972 (ECA) - which is the statute giving domestic effect to EU law in the UK - on Brexit day. ${ }^{21}$ As dramatic as the latter may sound, it is legally uncontroversial: if the UK leaves the EU, then it no longer needs to give effect to EU law. But disentanglement of EU law from the devolved nations would also require amendment of the relevant parts of the devolved legislation and, given the different voting patterns and political and constitutional dynamics in Scotland and Northern Ireland, this may be far more controversial. $^{22}$ As to the massive amount of EU-inspired law in the UK, the UK government is likely to embark on a lengthy review exercise, with a view to deciding whether to repeal, adjust or preserve existing EU-derived laws and whether to follow EU regulation in the future. ${ }^{23}$ A UK government would be free to apply- in the sense of mirroring in UK law and practice - any future EU laws where it agrees on its content. ${ }^{24}$ In those areas that are devolved to Scotland under the Scotland Act, the same rationale applies to the Scottish Government and, in fact, in areas such as agriculture, fisheries, environment policy, criminal justice and higher education EU competences to legislate will revert to the Scottish Parliament and not to Westminster. In these areas, the Scottish Government would be free to retain already incorporated EU law and mirror it in future legislation. Although the majority of legal opinion suggests that Scotland cannot do anything legally to prevent Brexit as $\mathrm{such}^{25}$, it could be that the refusal of legislative consent to the unpicking of EU law (through the varying of competence of the devolved institutions and legislation in devolved policy areas)

substantial effect on Swiss law. See further S. Jenni, 'Direkte und indirekte Europäisierung der schweizerischen Bundesgesetzgebung' (2013) 2 Leges 489.

${ }^{19}$ See House of Commons Foreign Affairs Committee, The Future of the European Union: UK Government Policy (SO, London, $1^{\text {st }}$ Report 2013-14), para 159.

${ }^{20}$ European Commission, EU-Swiss Relations, Press Release of 10 February 2014.

${ }^{21} \mathrm{https}$ :/publiclawforeveryone.com/2016/10/02/theresa-mays-great-repeal-bill-some-preliminary-thoughts/ ${ }^{22} \mathrm{https}$ //constitution-unit.com/2016/06/13/removing-references-to-eu-law-from-the-devolution-legislationwould-invoke-the-sewel-convention/

\footnotetext{
${ }^{23}$ However, academics have also explored the (large) extent to which EU law permeates US laws. See further A. Bradford, 'The Brussels Effect' (2012) 107 Northwestern University Law Review 1 and J. Scott, 'From Brussels with Love: The Transatlantic Travels of European Law and the Chemistry of Regulatory Attraction' (2009) 57 American Journal of Comparative Law 897.

${ }^{24}$ See A. Lazowski, 'Withdrawal from the European Union and Alternatives to Membership' (2012) 37 EL Rev. 523 and House of Commons, 'Leaving the EU', Research Paper 13/42, SO, London, 2013.

${ }^{25} \mathrm{https}$ ://publiclawforeveryone.com/2016/06/26/brexit-can-scotland-block-brexit/
} 
would preserve some of the status quo. ${ }^{26}$ As part of the Brexit negotiations, it may well be in the Scottish Government's interest to push for further devolution of legislative competence in those policy areas which are currently reserved matters and subject to EU competence where the Scottish Government wishes to abide by EU norms. Throughout all of this, steering a course that averts major constitutional crisis will be tricky.

\section{CONCLUSION}

Theresa May's commitment to reaching a "UK approach and objectives"27 prior to triggering Article $50 \mathrm{TEU}$ and for negotiations with the EU is a welcome political aspiration in the absence of any legal obligation (in UK or EU law) to involve the devolved administrations in the process of withdrawal from the EU. Assuming the UK Government does trigger the Article 50 TEU exit process, ${ }^{28}$ negotiations between the UK and the EU will begin apace, and run for, probably, at least two years. Designing and implementing a democratic deliberation process that facilitates a high degree of consent and coordination between the UK government, the UK parliament and all of the devolved authorities would seem to be imperative given the magnitude of the constitutional change occasioned by Brexit. Formal roles for these constitutional stakeholders will be crucial in order to minimise constitutional clashes and fragmentation but also in order to design a future relationship with the EU that genuinely reflects the positions and aspirations of all actors in the UK's devolved settlement: afterall they have a significant role to play in the implementation of the outcome, whatever it might be.

\footnotetext{
${ }^{26}$ This is particularly relevant in the area of free movement of EU citizens where the Scottish government and parliament have adopted a more principled stance than the Westminster government. See further https://www.theguardian.com/politics/2016/jul/05/nicola-sturgeon-acts-to-reassure-eu-nationals-scotland and http://www.scotsman.com/news/politics/nicola-sturgeon-scotland-needs-free-movement-of-people-1-4185479. ${ }^{27} \mathrm{http} / / / \mathrm{www}$.independent.co.uk/news/uk/politics/brexit-theresa-may-article-50-activated-uk-approach-eureferendum-scotland-sturgeon-a7138971.html

${ }^{28}$ Note that there are pending court cases on the matter of who should trigger Article $50 \mathrm{TEU}$. The core legal argument is whether the UK government can do this by 'Royal Prerogative', which gives the UK executive the power to negotiate treaties and conduct foreign relations, or whether Parliamentary approval is first required.
} 